\title{
THE INFLUENCE OF SPIRITUAL INTELLIGENCE,LEADERSHIP, AND ORGANIZATIONAL CULTURE ON ORGANIZATIONAL CITIZENSHIP BEHAVIOR: A STUDY TO ISLAMIC BANK IN MAKASSAR CITY
}

\author{
Muhdar. HM and St. Rahma \\ IAIN Sultan Amai Gorontalo \\ Universitas Negeri Gorontalo \\ (rahmasyam82@gmail.com,muhdar73@gmail.com)
}

\begin{abstract}
The aims of this study are to find out and to analys: (1) the influence of spiritual intelligence on organizational citizenship behavior; (2) the influence of leadership on organizational citizenship behavior; (3) the influence of organizationan culture on organizational citizenship behaviorThe population included all employees of Islamic Bank in Makassar City. There were 178 samples determined by using Slovin formula. The samples were selected in two stages: proportional and purposive sampling. The data were analyzed by using path analysis with the AMOS 21 program. The results show that: spiritual intelligence has a positive and significant influence on organizational citizenship behavior; leadership has a positive and significant influence on organizational citizenship behavior; organizational culture has a positive and significant influence on organizational citizenship behavior.

Penelitian ini bertujuan untuk mengetahui dan menganalisis: (1) pengaruhkecerdasan spiritual terhadap organizational citizenship behavior, (2) pengaruh kepemimpinan terhadap organizational citizenship behavior, (3) pengaruh budaya organisasi terhadap organizational citizenship behavior. Penelitianini bersifat deskriptif. Populasi penelitian adalah seluruh karyawan Bank Umum Syariah di Kota Makassar. Sampel yang diambil sebanyak 178 orang dengan menggunakan rumus Slovin.Pengambilan sampel dilakukan melalui dua tahap yaitu sampel proportional dan sampel purposif. Pengumpulan data dilakukan melalui observasi, wawancara, dan dokumentasi. Data dianalisis dengan teknik analisis jalur melalui program AMOS 2 .Hasil penelitian menunjukkan bahwa kecerdasan spiritual berpengaruh positif dan signifikan terhadap organizational citizenship behavior, kepemimpinan berpengaruh positif dan signifikan terhadap organizational citizenship behavior, budaya organisasi berpengaruh positif dan signifikan terhadap organizational citizenship behavior
\end{abstract}

Keywords: Spiritual intelligence, leadership, organizational culture, organizational citizenship behavior. 


\section{A. Introduction}

One of the global strategic issues in human resource management is gaining attention today is extra-role behavior commonly called organizational citizenship behavior (OCB). OCB is defined as an individual behavior that is discretionary not directly or explicitly recognized by the formal reward system, and aggregately will encourage organizations function more effectively ${ }^{1}$. OCB is employee behavior that is intended to improve the effectiveness of corporate performance without losing sight of the purpose of its own employee productivity $^{2}$.

Katz (1967) identified three employee behavior that is important to the effectiveness of the organization, namely the entry and stay in the organization as an employee; perform special roles required; and tied in innovative activities and spontaneous or unplanned who are outside roles performed ${ }^{3}$. The third behavior is called the OCB which is a behavior that is not directly or explicitly not to be in the formal system and the awarding organization. Such behavior is considered important because it is not determined standard, But influential in assessing the performance and effectiveness of the organization ${ }^{4}$.

The nature of from OCB is pragmatic so that it can be applied to the management of the organization, particularly with regard to human resources 5 . The organization will not succeed well or can not survive without its members who act as good citizenship ${ }^{6}$.OCB has a number of consequences, such as rising income levels, customer satisfaction, service quality, and profitability ${ }^{7}$. However, a number of researchers are still looking at the other side of OCB consequences $\mathrm{OCB}$ as a barrier to career advancement of individuals ${ }^{8}$ and

${ }^{1}$ Denis W. Organ, Organization Citizenship Behavior: The Good Soldier Syndrome,(Lexington, MA: Lexington Books, 1988) p. 160.

${ }^{2}$ Ibid.

${ }^{3}$ M.A. Konovskydan S.D. PughCitizenship Behavior and Social Exchange.Academy of Management Journal, 37 (3), 1994, 656-669

${ }^{4}$ P.M. Podsakoff, MichaelAhearne\& Scott B.MacKenzie, Organizational citizenship behavior and the quantity and quality of work group performance. Journal of Applied Psychology, Vol. 82, 1997, $262-270$.

${ }^{5}$ D. Shapiro\&B. Kirkman, Employees' reaction to the change to work teams: The influence of "anticipatory" injustice. Journal of Organizational Change Management, 12(1), 1999, 51-60.

${ }^{6}$ L. Markoezy\&K. Xin, The virtues of omission in Organizational Citizenship Bhaviour. http://www.goldmark.org, 2004

${ }^{7}$ M.C. Bolino, Citizenship and Impression Management: Good Soldiers or Good Actors? Academy of Management Review, 24 (1), 1999, 82-98

${ }^{8} \mathrm{C}$. Bergeron, Organizational Citizenship Behavior: A Negative Relationship to Career Outcome. Academy of Management Best Conference Paper, 2005 
increase the level of stress and work-family conflict ${ }^{9}$. Moreover, to rigid job and should always follow work procedures for safety,then it OCB is not appropriate to be applied ${ }^{10}$. In spite of that, OCB able to contribute to the achievement of effectiveness and organizational performance.Therefore, the position of OCB as a construct is a crucial factor in the organization.Said to be crucial, because it can improve the performance of the organization.Therefore, OCB important to be studied in relation to spiritual intelligence, leadership and organizational culture.

Spiritual intelligence plays a major role for the success of a person in work ${ }^{11}$.Because, spiritual intelligence is part of the intelligence that can facilitate a person's mind to solve of everyday problems in the achievement of objectives ${ }^{12}$. Empirically, several studies such as Doostar et al., (2012), Rastgar et al., (2012), and Rashvand and Bahrevar, (2013) found a positive correlation between spiritual intelligence with OCB.Spiritual intelligence makes employees look for meaningful work and creates a working environment that is profitable to encourage creativity and talent for development ${ }^{13}$. Organization managers must prepare the right atmosphere and increase the workplace spirituality where employees want to engage behaves $\mathrm{OCB}^{14}$.People who intelligent of spiritually will be involved in extra-role behavior ${ }^{15}$.

${ }^{9}$ M.C. Bolino, W.H. Turnley, Going the extra mile: Cultivating and managing employee citizenship behavior. Academy of Management Executive, 17(3), 2003, 60 71.

${ }^{10}$ S.T. Hunt, On The Virtues of Staying 'Inside of The Box': Does Organizational Citizenship Behavior Detract from Performance in Taylorist Jobs? International Journal of Selection and Assessment, 10 (1/2), 2002, 152-159

${ }^{11}$ Danah Zoharand Ian Marshall. SQ: Memanfaatkan SQ dalam Berpikir Holistik untuk Memaknai Kehidupan. Cetakan Kelima. terjemahkan oleh Rahmani Astuti, Ahmad Nadjib Burhani \& Ahmad Baiquni,(Mizan, Bandung: Mizan: 2002). p

${ }^{12}$ R.A. Emmons, Spirituality and intelligence: Problems and prospects. International Journal for the Psychology of Religion, 2000, 10, 57-64.

${ }^{13}$ MohammadDoostar,Godarzvand Mehrdad Chegini, SitaPourabbasi, Survey of Relationship between Spiritual Intelligence and Organizational Citizenship Behavior, Interdisciplinary Journal Of Contemporary Research In Business. Vol. 3, NO 11, 2012., 54.

${ }^{14}$ Abbas Ali Rastgar, AzimZarei,Seyed Mehdi Mosusavi Davoudi, KiarashFartash, The Link Between Workplace Spirituality, Organizational Citizenship Behavior And Job Performance In Iran, ArthPrabhand: A Journal of Economics and Management, Vol.1 Issue 6, September 2012, 51 - 67

${ }^{15}$ Omid Rashvand, and ElhamBahrevar, A Study of the Relationship among Spiritual intelligence, Organizational Citizenship Behavior and Turnover Intentions. International Journal of Research in Organizational Behavior and Human Resource Management, Vol. 1, No. 2, 2013, 25-34. 
Another factor that can influence the OCB is leadership. Leadership is one of the key factors in the life of the organization.An organization will succeed or fail even largely determined by factors of leadership ${ }^{16}$. Therefore, the role of the leader is very large for corporate success in achieving its objectives.From them appear new ideas and innovation in the development of the company. That is why, leaders tend to use certain ways it deems most effective, which is commonly called leadership style ${ }^{17}$.

Leadership style into the spotlight is transformational and transactional leadership.Transformational leadership is to motivate followers to do more than expected through: (a) increasing the level of understanding of the followers of the usefulness and value of detailed objectives and ideal, (b) make followers beat their own interests for the sake of the team or organization, and (c) moving the follower to meet the needs of higher level ${ }^{18}$. Transactional leadership is a relationship between leaders and subordinates based on a series of transactions activities between are both ${ }^{19}$. Empirically,transformational leadership and transactional leadershipof influence on $\mathrm{OCB}^{20}$.

Another factor that can influence the OCB is the organization culture. However, the absence of agreement on the concept of organizational culture led to the emergence of varied understanding and controversy. There are two camps related to organizational culture. The first camps argued that "the organization is a culture." And the second camp argued that "the organization has culture."The first camps assume that organizational culture is the result of culture. Therefore, this flow emphasizes the importance of descriptive explanation on an organization.In contrast, the second flow of it gives emphasis on the factors the occurrence of culture in organizations and its implications on the organization, for example by doing managerial approach .

\footnotetext{
${ }^{16}$ MiftahThoha,Kepemimpinan dan Manajemen, Devisi Buku Perguruan Tinggi, (Jakarta: PT. Raja Grafindo Persada, 2010), p. 75.

${ }^{17}$ GaryYukl, Leadership in Organization. Terjemahan Yusuf Udaya, (Jakarta: Prenhalindo, 1998), h. 139.

${ }^{18}$ Jane M. Howell, and Bruce J. Avolio, Transformational Leadership, Transactional Leadership, Locus of Control, and Support for Innovation: Key Predictors of Consolidated-Business-Unit Performance, Journal of Applied Psychology, Vol. 78, No. 6, 1993, 891-902

${ }^{19}$ Ibid

${ }^{20}$ Lihat Philip Podsakoff, et al, Transformational Leader Behaviors And Their Effects On Followers' Trust In Leader, Satisfaction, And Organizational Citizenship Behaviors, Leadership Quarterly. Vol.7 no. 2, 1990. Abubakr Suliman \& Hanan Al Obaidli. Leadership and organizational citizenship behavior (OCB) in the financial service sector The case of the UAE. Asia-Pacific Journal of Business Administration.Vol. 5 No. 2. 2013, 115-134.
} 
Do not ignore the two camps mentioned above, this study tried to understand the culture through organization cultural theory approach by Edgar H. Schein.According to him, organizational culture refers to a system of shared meaning,espoused by members that distinguishes the organization against another organization.

This concept rests on the basic understanding of the culture is a pattern of basic assumptions that were created, developed by certain groups as learning to overcome the problems of external adaptation and internal integration are formal and implemented ${ }^{21}$.Empirical studies show that organizational culture positively correlated to $\mathrm{OCB}^{22}$.Values of higher organizational culture will causing a higher $\mathrm{OCB}^{23}$. The higher the organizational culture it can cause higher OCB,the consequences will be lead to a value higher employee performance $^{24}$. Strong culture in the organization of directing to enhance the

${ }^{21}$ Edgar H. Schein,. The Corporate Culture Survival Guide: Sense and Nonsense about Cultural Change. (San Francisco: Jossey-Bass Publishers, 1992). p.79

${ }^{22}$ Lihat Hakan Erkutlu. The moderating role of organizational culture in the relationship between organizational justice and organizational citizenship behaviors. Leadership \& Organization Development Journal, Vol. 32 No. 6, 2011, 532554.Jagannath Mohanty \& Nagpur PR. Bhabani, Influence Of Organizational Culture On Organizational Citizenship Behavior: A Three-Sector Study. Global Journal Of Business Research, Vol.6 No.1, 2012. Benny Hutahayan; Siti Endang Astuti; Kusdi Raharjo; Djamhur Hamid. The Efect Of Transformational Leadership, Organizational Culture, Reward To Organizational Citizenship Of Employee Behavior At PT. Barata Indonesia (Persero). Interdisciplinary Journal Of Contemporary Research In Business. Vol. 5, No. 6. 2013, 466-474. Wiwiek Harwiki, Influence of Servant Leadership to Motivation, Organization Culture, Organizational Citizenship Behavior (OCB), and Employee's Performance in Outstanding Cooperatives East Java Province, Indonesia. IOSR Journal of Business and Management (IOSR-JBM). Volume 8, Issue 5 , 2013, $50-58$

${ }^{23}$ Benny Hutahayan, Siti Endang Astuti, Kusdi Raharjo, Djamhur Hamid, The Efect Of Transformational Leadership, Organizational Culture, Reward To Organizational Citizenship Of Employee Behavior At PT. Barata Indonesia (Persero). Interdisciplinary Journal Of Contemporary Research In Business. Vol. 5, No. 6. 2013, 466-474.

${ }^{24}$ Wiwiek Harwiki, Influence of Servant Leadership to Motivation, Organization Culture, Organizational Citizenship Behavior (OCB), and Employee's Performance in Outstanding Cooperatives East Java Province, Indonesia. IOSR Journal of Business and Management (IOSR-JBM). Volume 8, Issue 5, 2013, 50-58 
commitment of employees to achieve organizational goals. It is very helpful to improve of employees performance ${ }^{25}$.

The phenomenon of spiritual intelligence, leadership, and organizational culture that has been described above, is believed to affect the formation of employeesOCB at every level of the organization, including Islamic Banks in Makassar.To see the effect of spiritual intelligence, leadership, and organizational culture of employees OCB, then do analysis on Islamic Banks in Makassar with the unit of analysis is the employees.In particular, it chooses Islamic Banks in Makassar because this city is the largest area of activity of Islamic Banks in eastern Indonesia.In general, choose of them of Islamic banking as a research study, because: First, Islamic Banking is an institution in the practice and management activities applying the principles of sharia terms with spiritual values, such as values of sincerity (do everything without expect in return), taawun (a Muslim help other brother), Ukhwah (loves his brother like love itself), mujahadah (earnest, observant, meticulous, careful berlombah-lombah in selfless kindness slightest).Spiritual values have historically sourced from religious values ${ }^{26}$.Second, the development and contribution of Islamic banking is very impressive, as seen in the data that office network as of October 2012 as many as 2,574, a sharp increase compared to 2008 , which only has 1,024 . Asset growth and Islamic business unit in October 2011 (yoy) has reached $48.1 \%$, with a market share of $\pm 3.7 \%$. Then grow $\pm 37 \%$ in October 2012 (yoy), bringing the total assets to Rp174,09 trillion $^{27}$.Third, workers who entered the Islamic banking sector continued to increase. Data showed that the labor absorbed as much as 10952 people (2008). 15443 people (2009), 20164 people (2010), and 27660 people (2011), 30875 people $(2012)^{28}$. Fourth, the high turnover of $5 \%$ (2009) increased to $10 \%$ $(2010)^{29}$.As a consequence, predicted of employees OCB of low Sharia Banking. Because empirically there is an inverse relationship between OCB

${ }^{25}$ Fakhar Shahzad; ZahidIqbal; MuhammadGulzar, Impact of Organizational Culture on Employees Job Performance: An Empirical Study of Software Houses in Pakistan. Journal of Business Studies Quarterly. Volume 5, Number 2. 2013,56 - 64

26 John Milliman, Andrew J. Czaplewski, Jeffery Ferguson,Workplace spirituality and employee work attitudes: An exploratory empirical assessment, Journal of Organizational Change Management, 16, 2003, 426-447.

${ }^{27}$ Bank Indonesia, Outlook Perbankan Syariah. Direktorat Perbankan

Syariah-2012, http://www.bi.go.id, 2013

${ }^{28}$ Bank Indonesia,Statistik Perbankan Syariah (Islamic Banking Statistics).http://www.bi.go.id, 2012.

29 Novita NababanChristine CN.Bank syariah butuh banyak pegawai, http://keuangan.kontan.co.id, 2012. 
with turnover ${ }^{30}$.Employees who have a low OCB has a tendency to leave the organization as compared to employees who have level of high OCB.

Based on the above phenomenon, then the main problem in this research is how the influence of spiritual intelligence, leadership, and organizational culture on employee OCB of Islamic Banks in Makassar. With sub problem formula: (1) Whetherof spiritual intelligence of significant and positive effect on employees OCB of Islamic Banks in Makassar? (2) Whether of leadership of significant and positive effect on employees OCB of Islamic Banks in Makassar? (3) Whetherorganizational culture of significant and positive effect on employees OCB of Islamic Banks in Makassar? (4) Which of spiritual intelligence, leadership and organizational culture are the dominant influence on employees OCB of Islamic Banks in Makassar?

Thereby, the research objective to be achieved is to know and analyze the influence of spiritual intelligence, leadership and organizational culture onemployees OCB of Islamic Banks in Makassar.The benefits to be achieved: First, the benefits of academic / theoretical: (1) may add scientific insight and critical power writer so as to improve the ability to understand the theories related to spiritual intelligence, leadership, organizational culture, OCB and also understand the reality of the matter in the world of islamic banking in Makassar. (2) can contribute and add references to the literature development of human resource management and organizational behavior, especially with regard to spiritual intelligence, leadership, organizational culture, and OCB organization. (3) for consideration and thought for other researchers who are interested in the issuethe authors of thorough.Second, the practical benefits: (1) to provide benefits implementable of spiritual intelligence, leadership, organizational culture, and employees OCB to Islamic Banking. (2) Becoming an input for Islamic banking organization to be able to analyze the problems it faces, especially in order to increase employees OCB through the development of spiritual intelligence, leadership, organizational culture.

The methods used. This research is a explanatory research.Explantion research are use to test the research hypothesis between hypothesizedvariables. Research Population are all employees of Islamic banks in Makassar city (Bank Muamalat, Bank Syariah Mandiri, Bank Syariah Bukopin, Bank BNI Syariah dan Bank BRI Syariah)with population total 322 employees. For take of

${ }^{30}$ Lihat Orhan Uludag, Sonia Khan, Nafiya Güden, The Effects of Job Satisfaction, Organizational Commitment, Organizational Citizenship Behavior on Turnover Intentions. Academic Journal. FIU Hospitality Review; Vol. 29 Issue 2, 2011. Xiao-Ping Chen; Chun Hui; Douglas J. Sego, The Role of Organizational Citizenship Behavior in Turnover: Conceptualization and Preliminary Tests of Key Hypotheses. Journal of Applied Psychology, 83, 1998, 922-931. 
refresentative sample, the use Slovin formula. Thus obtained samples totaling 178 employees, that is supervisor 23 and staft/operational 155. The samplingtechnique used in this study was fase two (proportional sampling dan purposive sampling). Data was collected by distributing questionnaires to 200employees, which returns 183 and are processed only 178, because 5 not completed.

Measurement of variables. There are 4 variables used in this study include spiritual intelligence, Leadership, OrganizationalCulture, and OCB. Spiritual intelligence is measured based on the proposed model of spiritual intelligence King andDeCicco (2009) is Personal Meaning Production (PMP); Transcendental Awareness (TA); Conscious State Expansion (CSE);Existential and Critical Thinking (CET). Leadership is measured based on the model of Bass \& Avolio, 1994 is an ideal Influence,Inspirational Motivation, Intellectual Stimulation, the individuals Confederation, reward contingen, Active Control, PassiveControl. Measured based on the concept of organizational culture Hafidhuddin and Tanjung (2003), namely Shiddiq (Integrity),Istiqamah (Consistency), Fathanah (Professional), Amanah (Responsibility), and Tabliq (Communication). OCB is measuredbased on five dimensions proposed Organ (1988), namely altruism, conscientiousness, sportsmanship, courtesy, and civic virtue.Each dimension of the indicator variable using a Likert scale ranging from 1 (strongly disagree) to 5 (strongly agree).Data analysis techniques in this study, using path analysis through AMOS. 21 program. The output of the analysis of the influence values obtained directly. In order to test thevalidity and reliability of instruments tend to use the value of the correlation coefficient (r) at the significance level of $5 \%$ or 0.05 and Cronbach's alpha coefficient.

\section{B. Organizational Citizenship Behavior (OCB)}

OCB is defined as individual behavior that is discretionary, notdirectly or explicitly recognized by the formal reward system, and that in the aggregate promotesthe effective functioning of the organization ${ }^{31}$. Resemble OCB with pro-social ethical behaviorssuch as helping new employees to understand the internal workings of the organization, assistingco-workers complete their jobs, attending meetings and volunteering to do things in excess of jobprescriptions are some of the behaviors that can be associated with $\mathrm{OCB}^{32}$.

Organizations will benefit from a boost employee to engagein OCB, because it has been proven to increase productivity, efficiency and customer

\footnotetext{
${ }^{31}$ Denis W. Organ, Loc. Cit

${ }^{32}$ Abbas Ali Rastgar, Loc. Cit
} 
satisfaction, and reduce costs and turnoverrates and absenteeism ${ }^{33}$. Although OCB is a spontaneous initiative taken by the employee, OCB can bepromoted in the workplace through employee motivation, as well as giving them the opportunity to display OCB; ie creating awork environment that not only allows, but the circumstances are conducive to support OCB.Therefore management should beeducated about the OCB, and consider having OCB included in the performance evaluation in order to actively encourage amongemployees ${ }^{34}$. This risearch useful five dimensions of OCB by Organ (1988), namely: altruism,conscientiousness, sportsmanship, courtesy, and civic virtue. Definition of each of them is shown in table 1.

\section{TABEL 1: DEFINTION OF THE FIVE DIMENSIONS OF OCB}

\begin{tabular}{|l|l|l|}
\hline No & \multicolumn{1}{|c|}{ Agent } & \multicolumn{1}{|c|}{ Definition } \\
\hline 1 & Altruism & $\begin{array}{l}\text { Voluntary actions that help a fellow employee in } \\
\text { work related problems. }\end{array}$ \\
\hline 2 & Conscientiousness & $\begin{array}{l}\text { A pattern of going well beyond minimally required } \\
\text { role and task requirements. }\end{array}$ \\
\hline 3 & Sportsmanship & $\begin{array}{l}\text { A willingness to tolerate the inevitable } \\
\text { inconveniences and impositions that resultin an } \\
\text { organization without complaining and doing so with } \\
\text { a positive attitude. }\end{array}$ \\
\hline 4 & Courtesy & $\begin{array}{l}\text { The discretionary enactment of thoughtful and } \\
\text { considerate behaviors that preventwork related } \\
\text { problems for others. }\end{array}$ \\
\hline 5 & Civic Virtue & $\begin{array}{l}\text { Voluntary participation in, and support of } \\
\text { organizational functions of both aprofessional and } \\
\text { social nature. }\end{array}$ \\
\hline
\end{tabular}

\section{Spiritual Intellegence}

Spiritual Intelligence is an intelligence whichencounters question of meanings or 'values', whereby the intelligence places our characters andlife in a broader and richer context of meanings as well as the intelligence to evaluate a person'saction or way of life which is more meaningful compared to

${ }^{33}$ Nathan P. Podsakoff, Steven W.Whiting, Philip M. Podsakoff \&Brian D. Blume, Individual and Organizational-Level Consequences of Organizational Citizenship Behaviors: A Meta-Analysis. Journal of Applied Psychology. Vol. 94, No. 1, 2009, 122-141.

$$
{ }^{34} \text { Ibid }
$$


others $^{35}$.The spiritual intellegency of between mediation of emotion to thought, spirit to body ${ }^{36}$. Spiritual intelligence as a mental capacity that is rooted in the non-material aspects of the transcendence of the facts andreality, in a statement, that spiritual intelligence is defined as a set of intellectual capacities that contribute to the awareness, integration, and application of adaptive nonmaterial and transcendent aspects of the existence of a person who directs the resultsof such profound existential reflections, increase in significance, recognition of the transcendent self, and mastery of spiritual condition ${ }^{37}$. While it, the model is formulatedKing \& DeCicco, (2008)a researcher of spiritual intellegency from Trent University in Peterborough, Ontario, Canada has to measure spiritual intelligence are: first, Critical Existential Thinking (CET). This component involvesthe ability to critically reflect upon the meaning, purpose, and existential issues or other metaphysical (eg, reality, the universe,space, time, death). Secondly, Personal Meaning Production (PMP). This component is defined as the ability to construct personalmeaning and purpose in all the physical and mental experience, including the ability to create and control life goals. As existentialthinking, personal meaning is often described as a component of spirituality requires consideration in the model of spiritualintelligence. Third, Transcendental Awareness (TA). This component involves the ability to see the transcendent dimension of theself (ie, transcendent self), of others, and of the physical world (eg, non-materialism, interconnectedness) for normal, to build astate of consciousness. Fourth, Conscious state expansion (CSE). the ability to enter a higher level of consciousness; achieve anunderstanding of pure consciousness, cosmic, unity, to oneness; for example, through contemplation, meditation, prayer, ritual of worship ${ }^{38}$.

\section{Leadership}

Leadership is a process where an individual influences a group to achieve a common goal ${ }^{39}$. This understanding is sharpened by Dubrin that leadership is

${ }^{35}$ Danah Zohar dan Ian Marshall. (2002). SQ: Memanfaatkan SQ dalam Berpikir Holistik untuk Memaknai Kehidupan. Cetakan Kelima. Terjemahan oleh oleh Rahmani Astuti, Ahmad Nadjib Burhani \& Ahmad Baiquni, (Bandung: Mizan, 2002).

${ }^{36}$ Michael Berman. Developing SQ (Spiritual Intelligence) Through ELT. Article 57, April 2001, http://www.eltnewsletter.com

${ }^{37}$ David B. King \& Teresa L. A.DeCicco. Viable Model and Self-Report Measure of Spiritual Intelligence. International Journal of Transpersonal Studies, 28, $2009,68-85$

${ }^{38}$ David B. King \& Teresa L. A.DeCicco.Op. Cit

39 PeterG.Northouse. Kepemimpinan: Teori dan Praktik, Edisi Keenam. Diterjemahkan oleh Ati Cahayani. (Jakarta Barat: Indeks, 2013). h.2 
the ability to instill confidence and the support of members of the organization to achieve organizational goals ${ }^{40}$.Stogdill in his book Handbook of Leadership, defines leadership as:. . . interaction between members or groups. Leaders are agents of change, those who act affects other people more than other people's actions affect them. Leadership occurs when one group member modifies the motivation or competencies of others in the group ${ }^{41}$. Thus, by definition Stogdill, leadership involves the use of influence. This definition emphasizes the importance Stogdill become agents of change capable of affecting the behavior and performance of followers.Researchers James MacGregor Burns's leadership in 1978 wrote a book called Leadership.In the book the winner of the pulitzer prizes this, Burns make important differences between the two types of leadership orientation: transformational and transactional.

Transactional leadership applying a process of economic exchange is carried out between leaders and subordinates ${ }^{42}$. In the transactions can talk about a way, quality of the work, reward system, and patterns of supervision. Therefore, the theory of transactional leadership intrinsically discuss reward systems, patterns, and the nature supervision for subordinates.Transformational leaders engage followers not just to get the achievement of something that has meaning, as a visionary change agent, but also to raise their morale to become leaders themselves (Avolio et al., 2004) ${ }^{43}$. Transformational leaders help followers grow and develop into a leader by responding to the needs of followers by empowering them and by aligning the goals and objectives of the followers, leaders, groups, and larger organizations. Much evidence suggests that transformational leadership can move followers to exceed expected performance, as well as causing high levels of satisfaction and commitment to the group and the organization of followers ${ }^{44}$.

${ }^{40}$ A.J. Dubrin. Leadership: Research Findings, Practices, and Skills, Third Edition. (Boston: Houghton Mifflin Company, 2001).

${ }^{41}$ I. David Bertocci. Leadership in Organizations : There Is a Difference between Leaders and Managers. (New York: University Press Of America, 2009), p. 5

${ }^{42}$ Bernard M. Bass. From transactional to transformational leadership: Learning to share the vision. Organizational Dynamics, 18, 1990, 19-31

${ }^{43}$ Ibid

${ }^{44}$ Bernard M. Bass \& R.E. Riggio.Transformational leadership, Second Edition. Lawrence Erlbaum Associates, (New Jersey London: Publishers Mahwah, 2006). p. 78 


\section{E. Organizational Culture}

Organizational culture is perceived values shared by members of an organization (organizationalsubunits) are expressed in terms of attitude in organizational behavior ${ }^{45}$. Organizational culture is a pattern of basic assumptions that a given group has external adaptation and internal integration, and that have worked well enough to be considered valid, and therefore, to perceive, think, and feel in relation to those problems ${ }^{46}$.Hopstede (Deresky, 2000), defines organizational culture as a whole pattern of thought, feeling and action froma social group that distinguishes with other social groups ${ }^{47}$. In the context of Islamic organizations, the workculture in Syariah Institution is a manifestation of work culture the exemplified by the Prophet, the termed with culture "SIFAT" which stands Siddiq (Integrity), Istiqamah (Consistency), fathanah (professional), Amanah (responsibility) and Tablig (communication) ${ }^{48}$.

\section{F. Hypothesis}

H1: There is a significantpositive effect of Spiritual intelligence on employees OCB of Islamic Banks in Makassar.H2: There is a significant positive effect of leadership on employees OCB of Islamic Banksin Makassar. $\mathrm{H} 3$ : There is a significant positive effect of organizational culture on employees OCB of Islamic Banks in Makassar.

\section{G. Result}

Respondents Characteristics. Characteristics of respondents giving an overview of the respondents surveyed. The majority of respondents in this study havebeen aged 23-30 years, 161 people or $90.45 \%$. Characteristics of respondents by sex showed that the majority of respondents inthis study were male, 95 people, or $53.37 \%$. Characteristics of respondents by education shows that the majority of respondents inthis study were undergraduate S.1 154 people or $86.52 \%$. Working lives of the respondents indicate that the majority ofrespondents in this study have a service life of more than 1-3 years, 112 people or $62.92 \%$.

${ }^{45}$ Jamie Prat and Phill Beaulieu, Organizational Culture in Public Accounting Firms An Empirical Study of The Impact of Leadership Style. Accounting Organization and Society. Vol. 20.No. 5. 1992, 405-450.

${ }^{46}$ Edgar H.Schein, The Corporate Culture Survival Guide: Sense and Nonsense about Cultural Change. (San Francisco: Jossey-Bass Publishers, 1999). p. 65

${ }^{47}$ Helen Deresky. International Management: Managing Across Boarders and Cultures. Third Edition, New Jersey: Prentice Hall Inc, 2000). p. 130

${ }^{48}$ Didin Hafhiduddin dan Hendri Tanjung. Manajemen Syariah, Cet. I; (Jakarta: Gema Insani Press, 2003). h. 72 
The Influence of Spiritual Intelligence, Leadership, and Organizational Culture on Organizational Citizenship Behavior: a Study to Islamic Bank in Makassar City

Hypothesis Test. This research equation structural of produce of path analysis model, as Figure 2.7.1.Based on the model of path analysis results this, then it can be done hypothesis test through path coefficient testing.

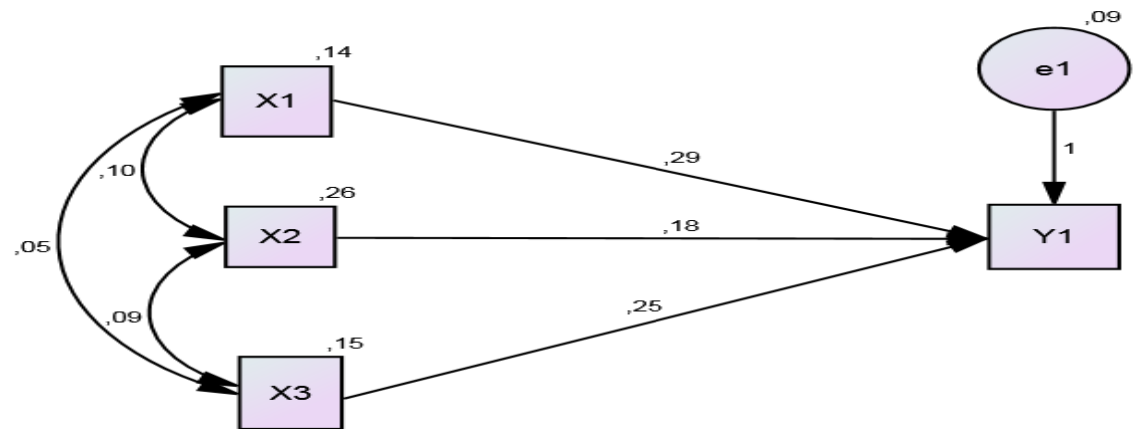

Picture2.7.1 : Model of Path Analysis Result

Table3.2.1 is hypothesis tes with view score $\mathrm{p}$ value, if score $\mathrm{p}$ value 0,05 atau $5 \%$, so related between variable are significant. The test results are presented in the following table 3.2.1:

Table3.2.1 Research Hypothesis Test

\begin{tabular}{|c|l|l|c|c|c|c|}
\hline HYP & \multirow{2}{*}{$\begin{array}{l}\text { VariabelInde } \\
\text { penden }\end{array}$} & $\begin{array}{c}\text { Variabel } \\
\text { Dependen }\end{array}$ & $\begin{array}{c}\text { Stand } \\
\text { ardize }\end{array}$ & $\mathbf{C R}$ & $\begin{array}{c}\text { p- } \\
\text { value }\end{array}$ & $\begin{array}{c}\text { Informati } \\
\text { on }\end{array}$ \\
\hline H1 & $\begin{array}{l}\text { Spiritual } \\
\text { Intellegence } \\
(\mathrm{X} 1)\end{array}$ & OCB (Y) & 0,29 & 4,069 & 0,000 & Significant \\
\hline H2 & $\begin{array}{l}\text { Leadership } \\
(\mathrm{X} 2)\end{array}$ & OCB (Y) & 0,18 & 3,372 & 0,000 & Significant \\
\hline H3 & $\begin{array}{l}\text { Organizational } \\
\text { Culture (X3) }\end{array}$ & OCB (Y) & 0,25 & 3,777 & 0,000 & Significant \\
\hline
\end{tabular}

Data Source: Processed from primary data, 2014

Overall of path three model of hypothesized, all of them significant. The interpretation of Table 3.2.1 can be explained as follows: (a) spiritual intelligence has significant and positive effect on OCB with $p=0.000>0.05$ with the coefficient of 0.29 , the coefficient shows that the better the spiritual 
intelligence of an employee, then OCB will the better. (b) leadership has a significant and positive effect on OCB with $p=0,0,00>0.05$ with a coefficient of 0,18 .This coefficient indicates that the better of an organization leadership, then OCB will be the better. (c) Organizational culture has a significant and positive effect on OCB with $p=0.000>0.05$ with a coefficient of 0.25 , this means that the better of organizational culture, thenOCB of the better. Whereas among spiritual intelligence, leadership and organizational culture of the dominant influence is spiritual intelligence with a value of 0.29 . While most small influence on OCB is leadership.

\section{H. Discussion}

To answer the problem formula and hypothesis 1 can be observed from path analysis in Table 3.2.1 were obtained by testing the structural model shows that spiritual intelligence has a positive and significant influence on OCB.The magnitude of the contribution of spiritual intelligence on OCB is $0.292^{2}=$ 0.0841 or $8.41 \%$. It is perceived that the employees of Islamic Banks in Makassar has the ability to give meaning to life so that he is able to adapt in a depressed employment situation, the employee can take hikma in it when he experienced a failure in work, and behind the experiences of employees can find the meaning of life inside it.Besides, they also recognizes that aspects of transcendental consciousness as consciousness to give recognition to the quality of the nonphysical, the consciousness to know the relationship between himself and others is an important part of the application of the values of spiritual intelligence in shaping the behavior of the employee OCB of Islamic Banks in Makassar.

Empirical studies are consistent with the research,among other things, Doostar et al., (2012); Rastgar et al., (2012); and Rashvand and Bahrevar (2013), which in principle say that there was a significant positive correlation between spiritual intelligence and OCB. Each component of spiritual intelligence as Critical Existential Thinking (CET), personal meaning production (PMP), transcendental awareness (TA) and the Conscious state expansion (CSA) effect on Organizational Citizenship Behavior (OCB $)^{49}$. Therefore, organizations are faced with that developed employees who are looking for meaningful work and create a working environment that is beneficial to encourage creativity and talents to develop themselves ${ }^{50}$. Organization managers must prepare the right atmosphere and improve the spirituality in the workplace where employees want to engage behave OCB, when employees see that the right situation is provided in the workplace, they

\footnotetext{
${ }^{49}$ Doostar et al., loc. cit

${ }^{50}$ Ibid
} 
are trying harder than ever to achieve organizational goals ${ }^{51}$.The people who spiritually intelligent will be involved in extra-role behavior. Therefore, the organization's managers can design an appropriate questionnaire measuring levels of employees spiritual intelligence; contributing to recruit personnel who the most potential intelligent of spiritually ${ }^{52}$.

To answer the problem formula and hypothesis 2 can be observed from path analysisresult in Table 3.2.1 were obtained by testing the structural model shows that leadership has a positive and significant influence on OCB.The magnitude of the contribution of leadership on employees OCB is $0.18^{2}=$ 0,0324 or $3.24 \%$. These results were obtained by measuring of leadership styles two (transformational and transactional).Turns out the transformational leadership style of employees perceived of Islamic Banks in Makassar greater influence on OCB with an average value of 3.92. While transactional leadership styles under fewer of influence on OCB with an average value of 3.88. Results of this study also indicate that good leadership will make the OCBis getting better. These findings are consistent with previous studies, among others Budiyanto and Oetomo (2011), Saeed et al., (2012), Zacher et al., (2013), who said that transformational leadership of positively and significantly correlated with OCB. While Podsakoff, et. al. (1990), Suliman\& Al-Obaidi (2013), transactional leadership of positively and significantly correlated with OCB.

Leadership that includes charisma, inspirational motivation, intellectual stimulation, and individualized attention is positively and significantly related to OCB. But in this study, intellectual stimulation perceived by employees of Islamic Banks in Makassar ofeffect greatest on OCB with an average value of 3.98. Followed by motivational inspiration (3.96), the influence of the ideal (3.94), and individual consideration (3.78).

Leadership encourages altruism, modesty (courtesy) and awareness (conscientiousness) on employees, so as to improve the behavior of the employee OCB.Transformational leaders offollowers motivate to work beyond expectations and a significantly improved the look of altruism and consciousness.Modern leadership theory as transformational leadership provides answers to the challenges of a competitive and innovation faced by the organization.Transformational leaders can facilitate these changes during the process, by putting a value on the development of a vision by inspiring followers to pursue that vision. As a result, organizations have begun to incorporate the philosophy behind the model of transformational leadership in management development program ${ }^{53}$.

\footnotetext{
${ }^{51}$ Rastgar et al., Loc. Cit

${ }^{52}$ Rashvand dan Bahrevar Loc. Cit

${ }^{53}$ Saeed et al., Loc. Cit
} 
Podsakoff et al. showed a significant relationship between each of transformational leadership factor (including contingent reward behavior) and $\mathrm{OCB}^{54}$. The most important of factors of transformational leadership is all correlated significantly with the dimensions of altruism, conscientiousness, courtesy, and sportsmanship.Additionally, a significant relationship was also observed between each construction transformational and civic virtue, and between contingent reward behavior and civic virtue dimension.Overall, these results suggest that the transformational leaders have a consistent positive impact on any form of $\mathrm{OCB}^{55}$. Suliman and Al-Obaidi (2013), explains that subordinates show help and subservient behavior when they see the charismatic or transformational leaders.Besides of transformational, transactional leadership according toSuliman and Al-Obaidi (2013) showed a significant relationship with OCB.Similarly Podsakoff et al., (1990), Piliai et al., (1999), Mackenzie et al., (2001), which shows a direct relationship between transactional leadership and OCB.Explained that if a manager / leader of positive feedback give on thecitizenship behavior of a particular, then the impact on the positive relationship between transactional leadership and OCB.Even if the rewards of be managed of contingentlyby manager / leader, then employees will feel that they are being treated fairly and trust them, as a result, will increase their willingness to engage in OCB.Similarly, the level of penalties should be perceived as fair by employees, and thus in the end of improve the employees $\mathrm{OCB}^{56}$.

To answer the problem formula and hypothesis 3 can be observed from path analysis result in Table 3.2.1 were obtained by testing the structural model shows that organizational culture has a positive and significant influence on OCB. The magnitude of the contribution of organizational culture on employees OCB is $0.25^{2}=0,0625$ or $6.25 \%$. The results obtained through dimension five measure of cultural organizations of Islamic Banks in Makassar (integrity, consistency, professionals, responsibility and communication culture).Turned out of integrity culture of includes honest behavior,think clearly, and strive to provide exemplary in working of employees perceived of Islamic Banks in Makassar greater of influence on OCB with an average value of 4.52. Whereas communicationculture which include information transparency, communicative, and visionaries who perceived the smallest of influence on employees OCB of Islamic Banks in Makassar with an average value of 4.23.It also hinting that organizational culture is one factor that important role in determining the high or low of an employe OCB.The better the organizational culture that owned Islamic Bank in Makassar, will encourage improvements in the OCB of an

\footnotetext{
${ }^{54} \mathrm{Ibid}$

${ }^{55} \mathrm{Ibid}$

${ }^{56}$ Mackenzie et al., Loc. Cit
} 
employee in the organization. Conversely, if the organizational culture is not good, OCB employees tend also not good.

These findings, theoretically of consistent with the view that a strong corporate culture has a considerable influence on employees behavior in this respect $\mathrm{OCB}^{57}$.Strong organizational culture as a trigger of $\mathrm{OCBvital}^{58}$.In a strong culture, core values of an organization or company is very deeply held and especially on employeesall, a growing number of employees who accept these values and greater commitment to her then the stronger the company culture it.This strong culture will establish cohesiveness, loyalty, and commitment to company that ultimately OCB well formed. Empirical studies are consistent with these studies, among others, performed by Mohanty et al., (2012); Hutahayan et al., (2013); Harwiki (2013), which in principle says that organizational culture of positively and significantly correlated with OCB.Mohanty and Rath (2012) suggests that there is a positive correlation between organizational culture and OCB in organizations all (Manufacturing, IT, Banking).These results also showed corelation degree of significant between organizational culture and OCB in the organization and further dimensions all of organizational culture has a positive correlation with dimensions of OCB which consists of Altruism, sportsmanship, Civic virtue, Conscientiousness, and courtesy $^{59}$. Hutahayan, et.al., 2013, found that organizational culture has a positive and significant impact on OCB. Organizational culture valuesof higher will causing a higher OCB.The better the organizational culture as seen from the increased innovation, stability, respect, results orientation, attention to detail, team orientation, aggressiveness and competitive will lead to OCB better. The impact of improvements in OCB will appear on the high altruism, consciousness, sportsmanship, courtesy and employees civic virtue ${ }^{60}$. Similarly, research Harwiki (2013), which is one of the findings is the organizational culture has positive influence on OCB,the higher organizational culture,can cause high OCB.In Wiwiek argument states that the organizational culture must evolve to support of employees styles to help others as a good cooperation. ${ }^{61}$.

${ }^{57}$ S.P. Robbins, Organizational Behavior Concepts, Controversies, and Aplication, Eight Edition, (EngelwoodClifts:Prentice-Hall, 1998) h. 107

${ }^{58}$ Denis W. Organ, Loc. Cit

${ }^{59}$ Mohanty \& Rath,Loc. Ci.t

${ }^{60}$ Hutahayan, et.al., Loc. Cit.

${ }^{61}$ Wiwik Harwiki, Loc. Cit. 


\section{Conclusions}

Conclusion.Based on the analysis result and discussion, be concluded: (1) spiritual intelligence is positive and significant effect on employees OCB of Islamic Banks in Makassar. The better the employees spiritual intelligence, the better the employee OCB. (2) Leadership is positive and significant effect on employees OCB of Islamic Banks in Makassar. The better the leadership of a leader, the better the employees OCB (3) Cultural organizations is positive and significant effect on employees OCB of Islamic Banks in Makassar. The stronger organizational culture, the more powerful it OCB (4) Among the spiritual intelligence, leadership and organizational culture are the dominant influence on OCB is spiritual intelligence. Whereas smallest influence is leadership.

Research Implications. This research has implications: (1) needs to be done further research on the different organizations with the same substance, in order to get a more comprehensive picture of the contribution of spiritual intelligence, leadership, and organizational culture on OCB. (2) To the policy makers should be to maximize the potential of spiritual intelligence of its employees, in order to increase of organizational OCB. (3) To leaders of Islamic banking should be implement a more effective leadership style (Leadership tyles that is able to motivate and employees inspire in improving their OCB).(4) To the policy makers, should make efforts in improvement of organizational culture and employees encourage to practice of culture values in organization life.

Research Limitations. Research has limitations and drawbacks: (1) from the aspect of methodology, the limitations can be observed at least in research instruments. Research instruments of designed using a Likert scale with perception answer choices five in the form of self-assessment.It is very vulnerable to the possibility of bias in the respondents' answers.(2) Spiritual intelligence is relatively new and measurement instruments of standard that have not, so the results of existing studies difficult to compare.(3) Islamic Bank which became the object of research with analysis unit of employees where confronted with the fact that the age and employees work experience are relatively young (less experienced) and science competence of dominated conventional science so feared understanding of respondents to the operation of Islamic banking is not deep. 
The Influence of Spiritual Intelligence, Leadership, and Organizational Culture on Organizational Citizenship Behavior: a Study to Islamic Bank in Makassar City

\section{REFERENCES}

Bank Indonesia 2012, StatistikPerbankanSyariah (Islamic BankingStatistics).http://www.bi.go.id.

Bank Indonesia 2013, Outlook PerbankanSyariah. DirektoratPerbankan Syariah-2012, http://www.bi.go.id

Bass, Bernard M., 1990, From transactional to transformational leadership: Learning to share the vision. Organizational Dynamics, 18.

Bass, Bernard M. \&Riggio, R.E., 2006, Transformational leadership, Second Edition. Lawrence Erlbaum Associates, New Jersey London: Publishers Mahwah.

Bergeron, C.,2005, Organizational Citizenship Behavior: A Negative Relationship to Career Outcome. Academy of Management Best Conference Paper.

Berman, Michael, 2001,Developing SQ (Spiritual Intelligence) Through ELT. Article 57, http://www.eltnewsletter.com

Bertocci, I. David, 2009, Leadership in Organizations : There Is a Difference between Leaders and Managers, New York: University Press Of America.

Bolino, M.C., 1999, Citizenship and Impression Management: Good Soldiers or Good Actors ? Academy of Management Review, 24 (1).

Bolino, M. C., Turnley, W. H., 2003, Going the extra mile: Cultivating and managing employee citizenship behavior. Academy of Management Executive, 17(3).

Christine CN; Nababan, Novita, 2012,Bank syariah butuh banyak pegawai, http://keuangan.kontan.co.id.

Deresky, Helen, 2000,International Management: Managing Across Boarders and Cultures. Third Edition, New Jersey: Prentice Hall Inc.

Doostar, Mohammad; Chegini, Mehrdad Godarzvand; Pourabbasi, Sita, 2012, Survey of Relationship between Spiritual Intelligence and Organizational Citizenship Behavior, Interdisciplinary Journal of Contemporary Research In Business. Vol. 3, NO 11.

Dubrin, A.J., 2001,Leadership: Research Findings, Practices, and Skills, Third Edition, Boston: Houghton Mifflin Company. 
Emmons, R.A., 2000, Spirituality and intelligence: Problems and prospects. International Journal for the Psychology of Religion, 10.

Hafhiduddin, Didin dan Tanjung, Hendri, 2003,Manajemen Syariah, Cet. I, Jakarta: Gema Insani Press.

Harwiki, Wiwiek, 2013, Influence of Servant Leadership to Motivation, Organization Culture, Organizational Citizenship Behavior (OCB), and Employee's Performance in Outstanding Cooperatives East Java Province, Indonesia. IOSR Journal of Business and Management (IOSR$J B M$ ). Volume 8, Issue 5.

Howell, Jane M and Avolio, Bruce J., 1993, Transformational Leadership, Transactional Leadership, Locus of Control, and Support for Innovation: Key Predictors of Consolidated-Business-Unit Performance, Journal of Applied Psychology, Vol.78, No.6.

Hunt, S.T., 2002, On The Virtues of Staying 'Inside of The Box': Does Organizational Citizenship Behavior Detract from Performance in Taylorist Jobs? International Journal of Selection and Assessment, 10 $(1 / 2)$.

Hutahayan, Benny; Astuti, Endang, Siti; Raharjo, Kusdi; Hamid, Djamhur, 2013, The Efect Of Transformational Leadership, Organizational Culture, Reward To Organizational Citizenship Of Employee Behavior At PT. Barata Indonesia (Persero). Interdisciplinary Journal Of Contemporary Research In Business. Vol. 5, No. 6.

King, David B. \& DeCicco, Teresa L., 2009, A.Viable Model and Self-Report Measure of Spiritual Intelligence. International Journal of Transpersonal Studies, 28.

Konovsky,M.A. dan Pugh, S.D. 1994. Citizenship Behavior and Social Exchange.Academy of Management Journal, 37 (3)

Markoezy, L \& Xin, K., 2004, The virtues of omission in Organizational Citizenship Bhaviour,http://www.goldmark.org.

Milliman, John; Czaplewski, Andrew J; Ferguson, Jeffery, 2003, Workplace spirituality and employee work attitudes: An exploratory empirical assessment, Journal of Organizational Change Management, 16.

Northouse, PeterG., 2013, Kepemimpinan: Teori dan Praktik, Edisi Keenam. Diterjemahkan oleh Ati Cahayani, Jakarta Barat: Indeks.

Organ, W. Denis, 1998,Organization Citizenship Behavior: The Good Soldier Syndrome, Lexington, MA: Lexington Books. 
The Influence of Spiritual Intelligence, Leadership, and Organizational Culture on Organizational Citizenship Behavior: a Study to Islamic Bank in Makassar City

Podsakoff, P.M; Ahearne, Michael; \& MacKenzie, Scott B, 1997, Organizational citizenship behavior and the quantity and quality of work group performance, Journal of Applied Psychology, Vol. 82.

Prat, Jamie\& Beaulieu, Phill, 1992, Organizational Culture in Public Accounting Firms An Empirical Study of The Impact of Leadership Style. Accounting Organization and Society. Vol. 20.No. 5.

Rashvand, Omid and Bahrevar, Elham, 2013, A Study of the Relationship among Spiritual intelligence, Organizational Citizenship Behavior and Turnover Intentions. International Journal of Research in Organizational Behavior and Human Resource Management, Vol. 1, No. 2.

Rastgar, Ali, Abbas; Zarei, Azim; Davoudi, Mousavi, Mehdi, Seyed; Fartash, Kiarash, 2012, The link between workplace spirituality, Organizational citizenship behavior and job Performance in iran. A Journal of Economics and Management. Vol.1 Issue 6.

Robbins, S.P., 1998, Organizational Behavior Concepts, Controversies, and Aplication, Eight Edition, EngelwoodClifts: Prentice-Hall

Schein, Edgar H., 1992, The Corporate Culture Survival Guide: Sense and Nonsense about Cultural Change, San Francisco: Jossey-Bass Publishers.

Schein,Edgar H., 1999,The Corporate Culture Survival Guide: Sense and Nonsense about Cultural Change, San Francisco: Jossey-Bass Publishers.

Shahzad, Fakhar; Iqbal, Zahid; Gulzar, Muhammad, 2013, Impact of Organizational Culture on Employees Job Performance: An Empirical Study of Software Houses in Pakistan. Journal of Business Studies Quarterly. Volume 5, Number 2.

Shapiro, D. \& Kirkman, B, 1999, Employees' reaction to the change to work teams: The influence of "anticipatory" injustice. Journal of Organizational Change Management, 12(1).

Smircich, Linda,1983, Concepts of Culture And Organizational Analysis. Administrative Science Quarterly, Vol. 28, No. 3.

Susan Tee Suan Chin, R.N. Anantharaman and David Yoon Kin Tong, 2011, The Roles of Emotional Intelligence and Spiritual Intelligence at the Workplace, Journal of Human Resources Management Research.Vol. 2011

Thoha, Miftah, 2010,Kepemimpinan dan Manajemen, Devisi Buku Perguruan Tinggi, Jakarta: PT. Raja Grafindo Persada. 
Yukl, Gary, 1998, Leadership in Organization. Terjemahan Yusuf Udaya, Jakarta: Prenhalindo.

Zohar, D. and I. Marshall, 2002, SQ: Memanfaatkan SQ dalam Berpikir Holistik untuk Memaknai Kehidupan. Cetakan Kelima. terjemahkan oleh Rahmani Astuti, Ahmad Nadjib Burhani \& Ahmad Baiquni, Bandung: Mizan.

Podsakoff, Nathan P; Whiting, Steven W; Podsakoff, Philip M; \& Blume, Brian D., 2009, Individual and Organizational-Level Consequences of Organizational Citizenship Behaviors: A Meta-Analysis. Journal of Applied Psychology. Vol. 94, No. 1. 